\title{
The measurement of human gonadotrophins by radioimmunoassay
}

\author{
G. V. Groom \\ Tenovus Institute for Cancer Research, Welsh National School of Medicine, \\ Heath Park, Cardiff CF4 4XX, U.K.
}

\section{Introduction}

The study of the gonadotrophins may be considered to have begun, perhaps, with the observation by Crowe, Cushing \& Homans (1910) that gonadal atrophy invariably followed hypophysectomy in dogs. A decade elapsed, however, before Evans \& Long (1921) demonstrated the effect of intraperitoneal administration of anterior pituitary tissue on oestrus and ovulation. Zondek (1930), after a series of papers on the biological properties of these pituitary factors, first used the terms Prolan A, now called follicle-stimulating hormone (FSH), and Prolan B, now called luteinizing hormone (LH). Forty years passed before the existence in man of the third gonadotrophin, prolactin, was finally established.

During this period many great developments occurred in methodology which were to revolutionize endocrinology. The transition from bioassay to the more sensitive and, supposedly, more precise radioimmunoassays (RIA) was probably one of the most significant of these changes. With the advent of this technique a reproducible, sensitive, specific and relatively simple method was available for the rapid monitoring of these hormones in biological fluids; a technique which became one of the most widely used methods in routine and research endocrine departments.

In recent years, few major developments have occurred in the technique of protein hormone RIA. The innovations have rather been in the use of hormone fragments or subunits for the production of new antisera. I will consider the use of some of these antisera, with particular reference to the difficulty of interpretation of data and the conflict between bioassay and RIA results. Evidence will be presented to demonstrate some of the limitations of RIA and suggestions for the future development of these assays put forward. Reference will be made to the RIA determination of human LH, FSH, chorionic gonadotrophin (HCG) and prolactin.

\section{Methods}

A simplified buffer system suitable for the RIA of a number of protein hormones, including those discussed herein, consists of $0.2 \mathrm{M}$-phosphate, $\mathrm{pH} 7 \cdot 5,1 \%(\mathrm{w} / \mathrm{v})$ human or bovine serum albumin, $0.05 \mathrm{M}$-EDTA and $0.1 \%(\mathrm{w} / \mathrm{v})$ merthiolate. The solution can be prepared at $\times 5$ concentration and stored at $-20^{\circ} \mathrm{C}$ until use when thawing and diluting in deionized water are the only operations required. Batches of fresh buffer concentrate need only be prepared at 3-4 month intervals depending on use, thus being economical on technician time and providing better continuity between assays over this period.

Only two additions need be made to this basic buffer. Normal rabbit serum (NRS, $0.25 \% \mathrm{v} / \mathrm{v}$ ) is added to the buffer used to prepare first antibody solutions, when the dilution of this antiserum is greater than $1: 1000(\mathrm{v} / \mathrm{v})$. The NRS serves as carrier in the double-antibody RIA method utilizing a first antibody raised in rabbits. When the first antibody is used at dilutions of less than 1:1000 the NRS concentration is adjusted to maintain a total rabbit globulin concentration of $0.25 \%(v / v)$ in the first antibody solution.

The second antibody solution is supplemented with Triton X-100 $(5 \% \mathrm{v} / \mathrm{v})$ which has been shown to have no deleterious effect on the performance of the assays but does expedite draining of the assay tubes after centrifugation and decanting, thus allowing counting of the radioactivity after a much shorter delay. In addition, considerable improvement in non-specific binding to less than $1 \%$ of counts added is obtained with the use of Triton. 


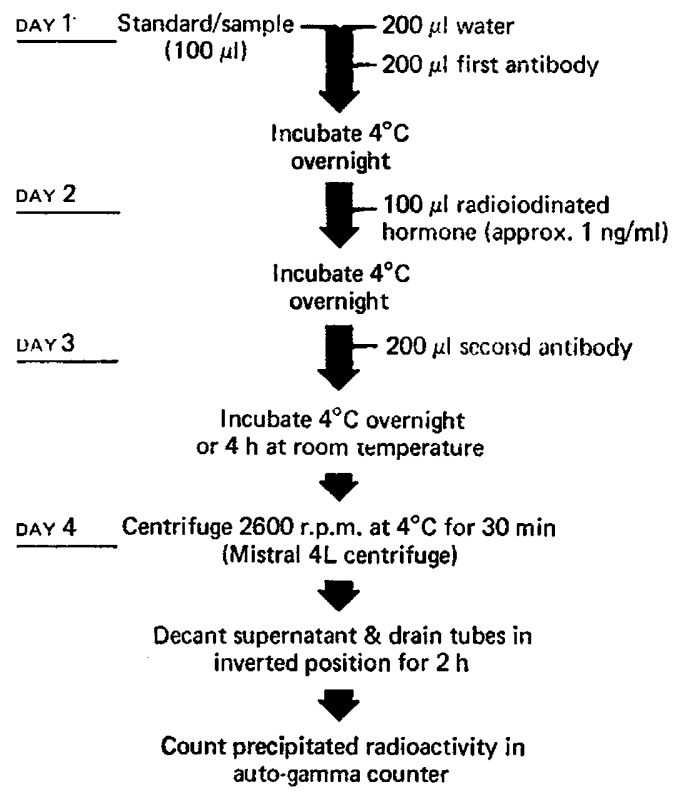

Text-fig. 1. The basic radioimmunoassay procedure employed for the determination of $\mathrm{LH}, \mathrm{FSH}, \mathrm{GH}$ or prolactin.

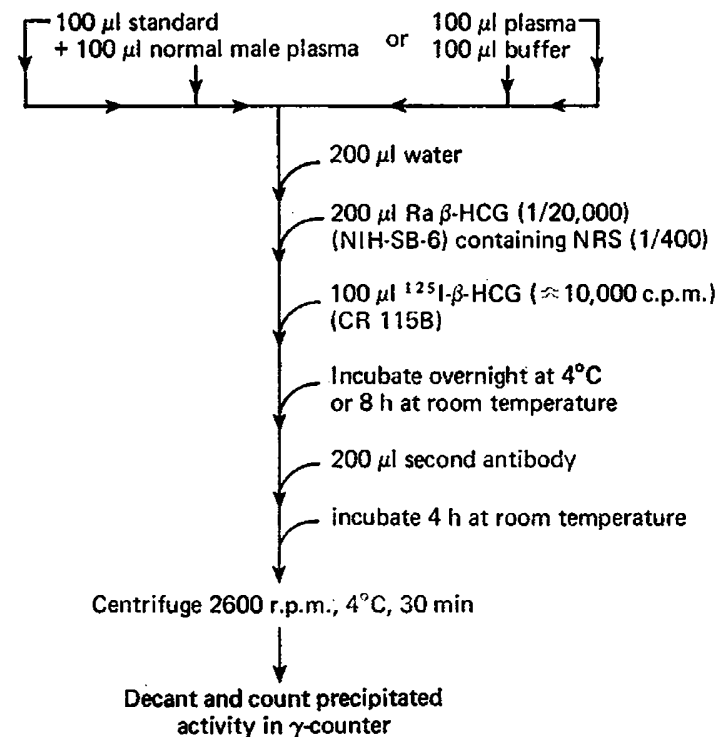

Text-fig. 2. Radioimmunoassay procedure employed for the determination of $\beta$-HCG.

The current procedure used for the assay of LH, FSH and prolactin is shown in Text-fig. 1. The method for the measurement of LH and FSH was modified from that described by Groom, Groom, Cooke \& Boyns (1971). Antisera to LH (F 87) and FSH (M 93) and purified FSH for labelling (CPDS 13), generously donated by Dr W. Butt, are used at final dilutions of $1: 240,000$ and $1: 500,000$ respectively. Dr A. S. Hartree kindly provided the LH for labelling (IRC-2).

The assay of human prolactin with antiserum raised to a pituitary extract (antiserum 7110; final dilution 1:60,000) is as shown in Text-fig. 1. The assay of human prolactin with antiserum raised to 
an amniotic fluid extract (antiserum R47; final dilution $1: 1200$ ) is that of Cole \& Boyns (1973) as modified by Cole, Groom, Link, Flanagan \& Seldrup (1976). Purified prolactin preparations for labelling and used in both assays were kindly provided by Dr U. J. Lewis. Further purified prolactin samples were kindly donated by Dr P. Lowry.

Materials for the assay of the $\beta$-subunit of HCG (Text-fig. 2) were generously provided by the National Institutes for Arthritic, Metabolic and Digestive Diseases (NIAMDD), Bethesda, Maryland.

Human growth hormone (GH) is assayed as outlined in Text-fig. 1, by using antisera obtained from Burroughs Wellcome Ltd, Beckenham, Kent (RD 16, final dilution 1:300,000), and purified growth hormone for labelling kindly donated by the M.R.C., National Institute for Medical Research, London.
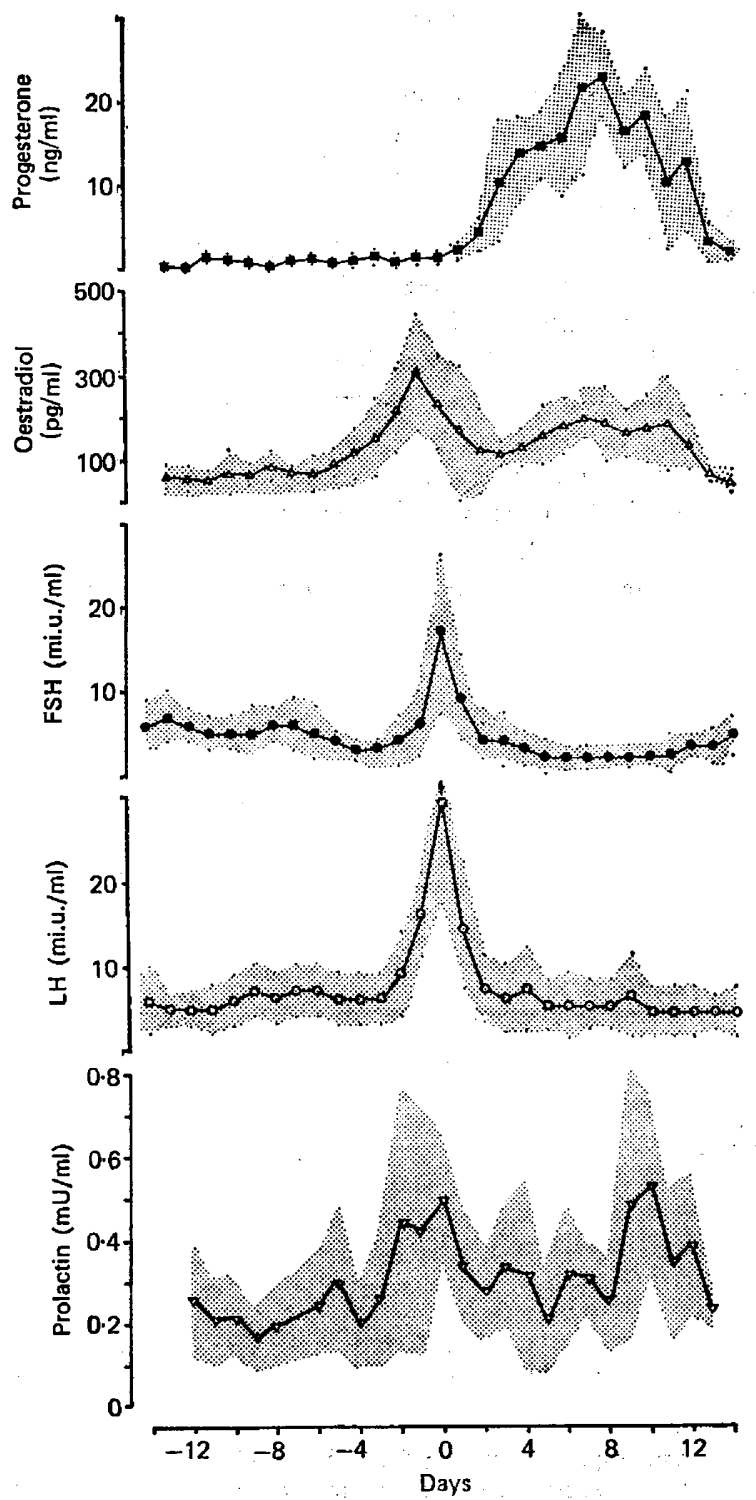

Text-fig. 3. Mean ( \pm S.D.) plasma levels of $\mathrm{LH}, \mathrm{FSH}$, prolactin, oestradiol and progesterone during the menstrual cycle $(\mathrm{N}=6)$. 
All iodinations were carried out with chloramine $\mathrm{T}$ after the method of Greenwood, Hunter \& Glover (1963) with subsequent purification on Biogel P-60 as described by Groom et al. (1971).

\section{Results and Discussion}

\section{Radioimmunoassay of $\mathrm{LH}$ and FSH}

Text-figure 3 shows the mean levels of $\mathrm{LH}$ and FSH in the plasma of 6 normal women bled daily throughout a menstrual cycle and relates these hormones to concomitant levels of prolactin, oestradiol and progesterone. The parallel secretion pattern of LH and FSH is clearly seen with the single major peak occurring at mid-cycle, after the oestradiol peak, and probably responsible for ovulation within the succeeding 24-72 h (Stevens \& Vorys, 1967). While the release of the egg is the classical role for $\mathrm{LH}$ no direct role for FSH has been described during mid-cycle. The simultaneous release of both hormones is, therefore, taken to be merely a necessary consequence of the dual-acting LHreleasing hormone (LH-RH).

The classical role of FSH, of course, is the development of the follicle and the secretion of oestradiol. The lack of any substantial peak in FSH levels during the early follicular phase of the cycle is difficult to understand. This is particularly so in view of the fact that earlier workers using bioassay techniques had found equivalent peaks of urinary FSH at mid-cycle and during the early follicular phase (Stevens \& Vorys, 1967). Follicular-phase levels of FSH determined by RIA are slightly higher than in the luteal phase but the conflict between RIA and bioassay observations of a distinct FSH peak during the early follicular phase remains to be resolved.

The early report of Schally et al. (1971) of a single releasing hormone responsible for the hypothalamic control of both LH and FSH was at first regarded with some doubt. However, no evidence has yet been produced to indicate the existence of a separate FSH-releasing hormone (Shahmanesh \& Jeffcoate, 1976). Furthermore, attempts to determine specific LH- and FSH-releasing moieties of the LH-RH decapeptide molecule have proved fruitless (Schally, Arimura, Debeljuk, Redding \& Reeves, 1973; Groom \& Boyns, 1973).

The LH-RH stimulation test has thus become an established and reliable test of both $\mathrm{LH}$ and

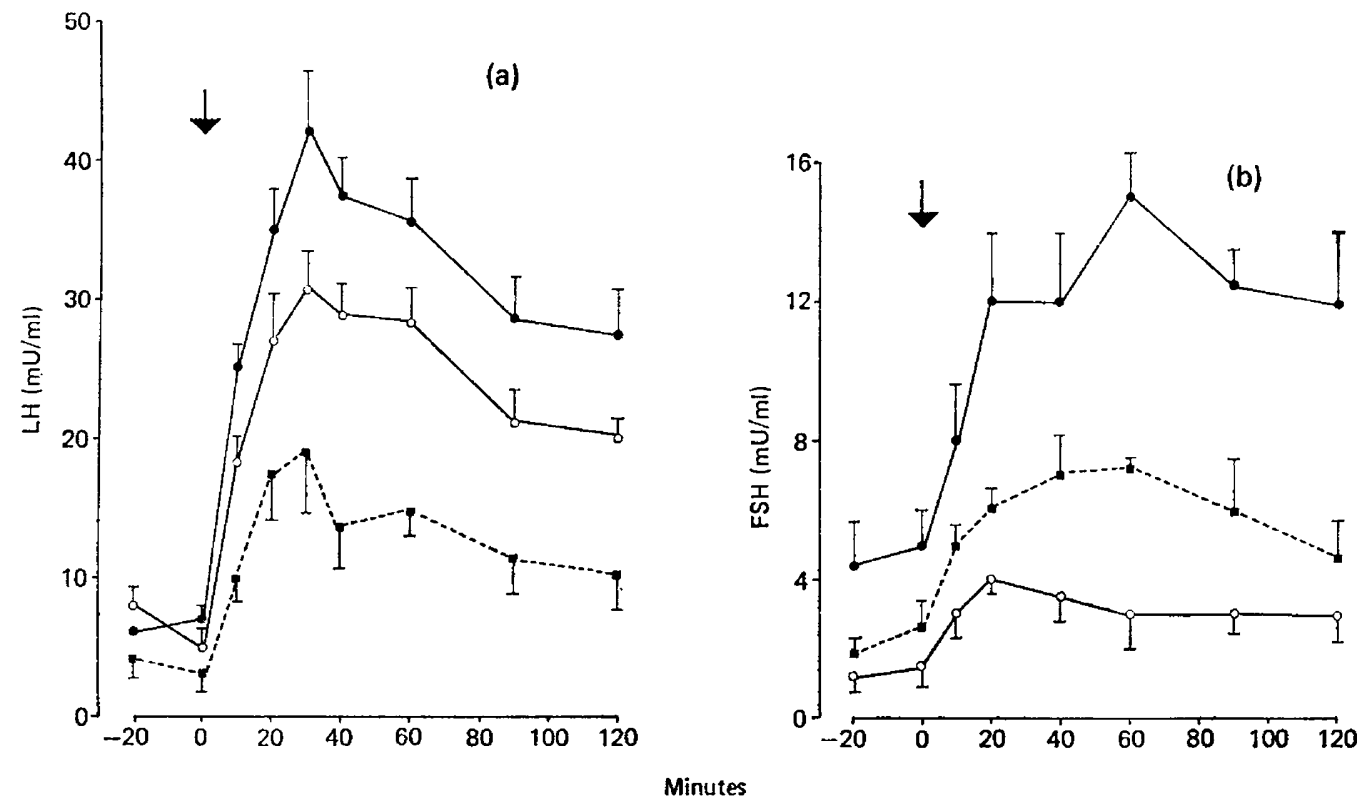

Text-fig. 4. Individual serum responses (mean \pm S.D.) of (a) LH and (b) FSH to intravenous administration of LH-RH (arrow) on three separate occasions to 3 volunteers. $\mathrm{B}, 100 \mu \mathrm{g} ; \mathrm{\square}$, Subject $\mathrm{C}, 50 \mu \mathrm{g}$. The response to the same dose was reproducible in each patient. (Modified from Shahmanesh et al., 1975.) 
FSH pituitary reserve. While there is variation between individuals given the same dose of the releasing hormone, the $\mathrm{LH}$ response to a given dose is very reproducible in the same subject (Textfig. 4a). Similarly, when one considers FSH release (Text-fig. 4b), there is a somewhat lower response to any dose of LH-RH and the time-course differs from the LH release pattern, but the same reproducibility is present. The response of the two hormones commences simultaneously and the discrepancies in time-course may reflect differences in metabolic clearance or half-life of the two hormones.

The LH-RH test is equally useful in men and women and can be extended to test ovarian/testicular response to the gonadotrophin stimulation. Great care must be taken in interpreting these data, however, since the action of other hormones may be limiting. For example, the normal oestradiol response after LH-RH stimulation is abolished when LH-RH is administered with chlorpromazine which stimulates prolactin secretion (Text-fig. 5). Elevated prolactin levels have been implicated in many cases of infertility, probably acting by a direct block on LH and FSH action at the ovary (Thorner, McNeilly, Hagan \& Besser, 1974).

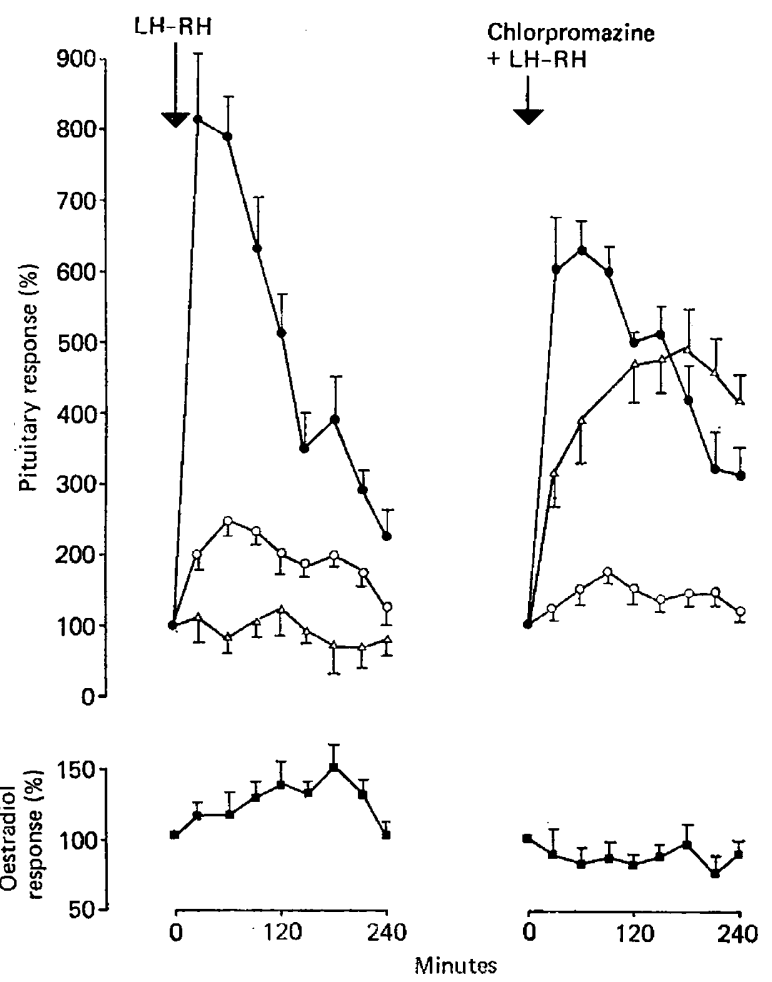

Text-fig. 5. Effect (mean \pm S.E.M.) of chlorpromazine ( $50 \mathrm{mg}$ i.m.) on the LH (๑), FSH (o), prolactin $(\triangle)$ and oestradiol ( $(\mathbf{E})$ response to LH-RH $(100 \mu \mathrm{g}$ i.m.) of 4 normal men. Results are expressed as a percentage of the value at zero time. (Modified from Cole et al., 1976.)

The presence of a common hypothalamic releasing hormone is but one aspect of the close relationship between LH and FSH. Considerable apparent redundancy has been shown between the biological activities of the two molecules. This topic was reviewed by Greep (1961) and Schwartz \& McCormack (1972) and will not be further dealt with here. However, the various biological activities attributed to the two hormones could be accounted for by a single molecule producing effects which may be modified by, or depend upon, the state of the target tissue. Furthermore, LH- and FSH-like material have been reported to be present in the same pituitary cell (Nakane, 1970), contrary to the generally held maxim of one cell-one hormone. Phifer, Midgley \& Spicer (1973), using extensively 
characterized, highly specific antisera, also observed both gonadotrophins in cells in human pituitary sections and supported their findings by biological staining techniques.

The specificity of antiserum to the gonadotrophins has always been a problem owing to the close chemical similarites of LH, FSH and the third pituitary glycoprotein, thyroid-stimulating hormone (TSH), and HCG. Human LH, FSH and TSH consist of two non-identical subunits each of approximately 100 amino acids (Reichert \& Midgley, 1968; Liao \& Pierce, 1970; Ryan, Jiang \& Hanlon, 1971). The primary sequence of the $\alpha$-subunit is identical for the three hormones in any species, while the hormone-specific $\beta$-units still exhibit considerable homology. This similarity of structure leads to problems of chemical purification while, in addition, the normally covalently bound subunits can readily dissociate and re-associate. This recombination of subunits has been shown to be possible not only between different hormones within a species, but also between subunits from hormones of different species (Table 1). The dimeric nature of these hormones with its inherent lability creates further problems to the chemist attempting to purify the molecules with as little structural damage as possible. Furthermore, excessively harsh conditions of iodination of this purified hormone by the RIA technician could lead to further alteration and polymerization of the molecule. Unless suitable purification steps are subsequently taken, spurious results could be obtained with this damaged tracer in an RIA.

Table 1. Recovery of biological activity after recombination of glycoprotein hormone subunits

\begin{tabular}{llcl}
\hline$\alpha$-Subunit & $\beta$-Subunit & $\begin{array}{c}\text { Activity } \\
\text { recovered }\end{array}$ & Reference \\
\hline LH & TSH & TSH & \\
TSH & TSH & TSH \\
TSH & LH & LH & Liao \& Pierce, 1970 \\
Rat LH & Rat LH & LH & Ward et al., 1971 \\
Ovine FSH & Ovine FSH & FSH \\
Ovine LH & Ovine FSH & FSH \\
Ovine FSH & Ovine LH & No activity & Papkoff \& Samy, 1967 \\
Human LH & Bovine LH & LH & Reichert, Midgley, Niswender \& Ward, 1970 \\
\hline
\end{tabular}

Pituitary glycoprotein subunits have been shown to exist in normal plasma (Franchimont, Gaspard, Reuter \& Heynen, 1972; Hagen \& McNeilly, 1975) and can be released from the pituitary in response to LH-RH and TRH in certain clinical conditions (Kourides, Weintraub, Ridgway \& Maloof, 1973; Benveniste, Frohman, Bell, Spitz \& Rabinowitz, 1975). Their properties, however, are completely unknown. Virtually none of the biological activity of the intact hormone remains in either subunit but almost complete activity returns after recombination (Table 1). McKerns \& Ryschkewitsch (1974) showed that the subunits of LH can compete and inhibit LH activity at the corpus luteum. To date, however, the search for subunit activity has been largely short-sighted and much work remains here in searching for activity in the many possible target tissues.

Several workers have shown the existence of 'big' precursor hormones for insulin, parathyroid hormone and adrenocorticotrophin, and even 'big-big' antecedents of these molecules. Could it be that LH is the 'big' precursor of $\beta$-LH while the $\alpha$-subunit is only a carrier, as suggested by Franchimont et al. (1972)? Conversely, could the LH-FSH complex be a 'big-big' gonadotrophin? What biological activity, if any, would such a molecule possess and what changes in pituitary secretion rates of this material would be measured if a suitable assay existed? Young, Harsoulis, Kuku \& Fraser (1975) reported that the major form of LH in human plasma and pituitary was of molecular weight in excess of 70,000 while that in urine was of 30,000 or less. Since the molecular weight of each subunit, calculated from its primary sequence, is of the order of 15,000 it would appear that plasma and pituitary LH is largely present in the form of a tetramer molecule.

Many questions remain to be answered concerning the nature of gonadotrophins. The weight of evidence suggests, however, that because they have largely parallel secretion patterns, a single 
hypothalamic releasing hormone, exist in the same pituitary cell, and exhibit such overlapping chemical and biological activity, LH and FSH may well be fragments of a larger molecule with, perhaps, still other biological properties.

\section{Radioimmunoassay of $\beta-H C G$}

The $\beta$-subunit of HCG differs from that of LH merely in the composition of a dozen amino acids through the molecule, the presence of additional carbohydrate moieties, and a further sequence of 32 amino acids at the C-terminus (Shome \& Parlow, 1973; Bahl, Carlsen, Bellisario \& Swaminathan, 1972), while the $\alpha$-subunits of the two molecules are identical. It is because of this considerable structural homology, that antisera raised to one hormone show a great degree of cross-reactivity with the other. With the availability of purified subunits and subunit fragments, however, antisera have been produced to give much reduced cross-reaction. Text-figure 6 illustrates the lack of cross-reaction with LH, FSH, TSH and the $\alpha$-subunit in a $\beta$-HCG assay. With this assay, pregnancy can be detected at a very early stage when previous non-specific assays could not have distinguished it from a rise in pituitary gonadotrophin (Text-fig. 7).

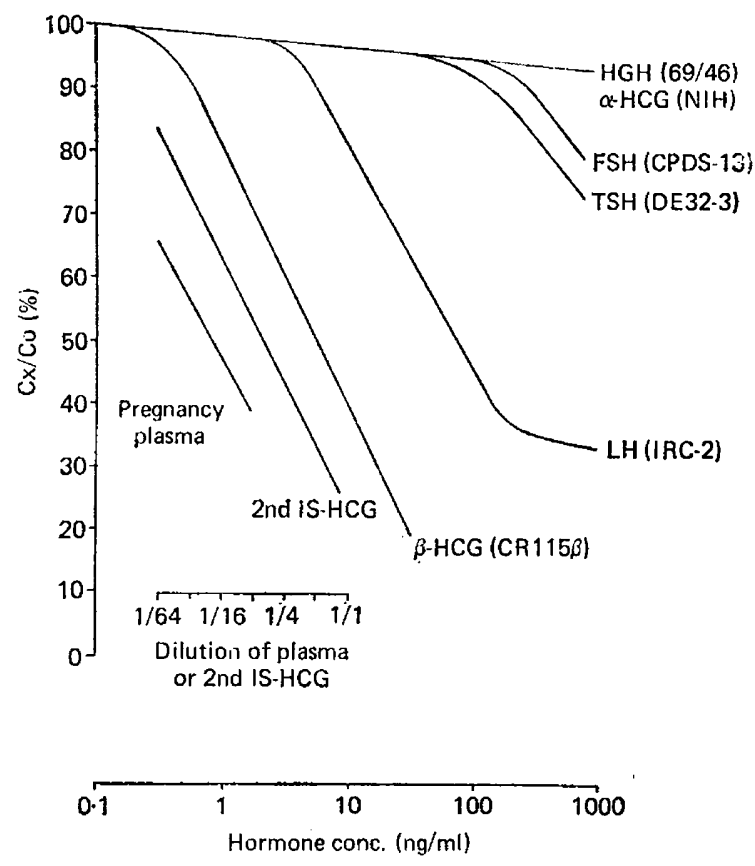

Text-fig. 6. Effect of various pituitary and placental hormone preparations and pregnancy plasma on the assay for $\beta-H C G$.

The presence of HCG in the plasma of non-pregnant women is indicative of a pathogenic condition and work is underway in many centres to determine the usefulness of the $\beta$-HCG assay as a tumour marker determinant (Rees, 1975). The assay is of proven worth in detecting trophoblastic tumours (Vaitukaitis, Braunstein \& Ross, 1972) and has been found in the plasma of approximately $50 \%$ of patients with ovarian or testicular tumours, as well as, to a lesser extent, in those with gastrointestinal or lung tumours (Vaitukaitis, 1975a).

As part of our studies into tumour markers in breast and prostatic cancer, a series of samples from control populations was assayed. These samples were derived from three sources: young, healthy laboratory technicians, or a random collection of plasma samples acquired by the MRC Epidemiology Unit from the South Wales area, or a collection of samples from patients hospitalized for non- 


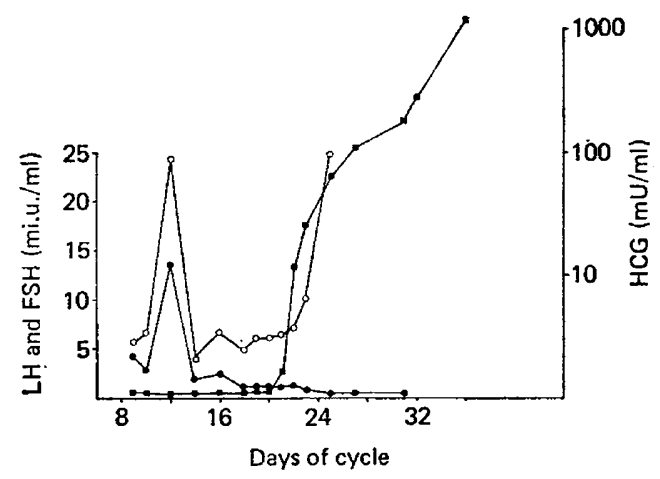

Text-fig. 7. Plasma gonadotrophin levels during conception. Estimations of LH (O), FSH (๑) and HCG (D) were made with the assays described. The LH assay measured LH and HCG indiscriminately in the plasma.

endocrine, non-tumour symptoms. The results of $\beta$-HCG analysis of these samples are shown in Table 2. The gradation of $\beta$-HCG-positive values from the healthy group through the intermediate random population to the ill, hospitalized group is quite marked and it now seems clear that $\beta$-HCG is present in other non-neoplastic states, a problem found in other plasma tumour marker assays, e.g. heterogeneity and instability of iodinated HCG (Griffiths \& Godard, 1975), disparity of 'direct' and 'indirect' CEA assay (Loewenstein, Kupchick \& Zamcheck, 1976), homology of $\alpha$-fetoprotein and serum albumin (Rouslahti \& Terry, 1976), aggregation effect of $\alpha$-fetoprotein in RIA (Young, Reid \& Crawford, 1976) and presence of HCG in normal human testes (Braunstein, Rasor \& Wade, 1975). It also became apparent from our study that fresh plasma samples, carefully stored deepfrozen, were essential for accurate determination of $\beta-H C G$ because freezing and thawing and prolonged storage in the unfrozen state led to spurious results in the assay.

Table 2. Occurrence of $\beta-H C G$ in the plasma of three populations of control, non-cancerous subjects

\begin{tabular}{lccc}
\hline \multicolumn{1}{c}{ Population } & $\begin{array}{r}\text { No. of } \\
\text { subjects }\end{array}$ & $\boldsymbol{\beta}$-HCG present & $\%$ Positive \\
\hline Young laboratory staff & 20 & 0 & 0 \\
M.R.C. random home samples & 168 & 20 & 11 \\
Hospitalized patients & 85 & 26 & 31 \\
\hline
\end{tabular}

Braunstein et al. (1975) have reported the extraction of HCG-like material from normal testes and Vaitukaitis (1975b) has suggested that the gland may just be binding material secreted elsewhere in the body. Small amounts of $\beta-H C G$ have been measured in the secretions from normal gut in vitro (J. L. Vaitukaitis, personal communication). It is possible that $\beta-H C G$ and other so-called tumour markers may be secreted in very low concentrations from normal tissue and only in certain disease states do the levels rise above the lower limits of sensitivity of most assays. It is also possible, however, that these findings, and the effects observed after improper storage of the plasma samples, could be explained by the assay measuring some degraded fragment of a common protein constituent. The major antigenic determinant of $\beta$-HCG has been reported to lie in a conformational arrangement of the C-terminal 32 amino acids (Bahl, Pandian \& Ghal, 1976).

The presence of a tumour marker per se, therefore, does not identify the subject as tumour bearing directly and one must carefully define the population and the upper limit normal for that population with all such assays. Once these criteria are set, great use can be made of the tumour marker assays, such as that for $\beta$-HCG, for screening high-risk populations and monitoring progression and regression of the disease. 


\section{Radioimmunoassay of prolactin}

Until recent years no method existed for the discrete isolation and purification of human prolactin free from growth hormone although its biological manifestation and lactogenic action had long been described. Indeed, at one stage it was thought that mammotrophic action was an intrinsic property of growth hormone (see Boyns \& Griffiths, 1972 for review of this aspect). Two distinct hormones are now recognized and sensitive, specific bioassays and RIA exist for prolactin and GH in several species. Considerable research data have appeared in recent years and the extent of the important roles this hormone holds in regulating many body functions is still not fully realized. The increased availability of different assays for human prolactin has, however, still left a controversy over the basic secretion patterns of this hormone.

Table 3. Patterns of prolactin secretion during the menstrual cycle when measured by various bioassays and radioimmunoassays

\begin{tabular}{|c|c|c|}
\hline Reference & Assay & Conclusion \\
\hline $\begin{array}{l}\text { Coppedge \& Segaloff, } 1951 \\
\text { Berle, Apostolakis \& Link, } 1971\end{array}$ & $\begin{array}{l}\text { Bioassay } \\
\text { Bioassay }\end{array}$ & Mid-cycle and mid-luteal surges \\
\hline Robyn et al., 1973 & RIA & Mid-cycle and mid-luteal surges \\
\hline Ehara, Siler, Vandenberg, Sinha \& Yen, 1973 & RIA & $\begin{array}{l}\text { Levels higher in luteal than follicu- } \\
\text { lar phase }\end{array}$ \\
\hline $\begin{array}{l}\text { Hwang, Guyda \& Friesen, } 1971 \\
\text { del Pozo, Goldstein, Friesen, Brun del Re \& Eppenberger, } 1975\end{array}$ & $\left.\begin{array}{l}\text { RIA } \\
\text { RIA }\end{array}\right\}$ & No consistent pattern, random \\
\hline $\begin{array}{l}\text { McNeilly \& Chard, } 1974 \\
\text { Groom \& Griffiths, } 1976\end{array}$ & $\left.\begin{array}{l}\text { RIA } \\
\text { RIA }\end{array}\right\}$ & $\begin{array}{l}\text { Two populations of women, some } \\
\text { showing cyclic, some only random } \\
\text { fluctuation }\end{array}$ \\
\hline
\end{tabular}

The changes detected in plasma prolactin levels during the menstrual cycle by various assays are summarized in Table 3. While the results from the bioassays tended to show consistently cyclic patterns paralleling serum oestradiol levels, no consistency was seen when the samples were assayed by the RIA methods. This may be due partly to the differences between the volunteers selected for the various studies, since it is likely some women may not show any cyclic patterns in prolactin release or else do not do so regularly (Text-fig. 8). In addition, however, this disparity may well be due to the different assays used, i.e. to the 'specificity' of the assay.

Specificity in RIA usually refers to the characteristic of the antiserum to combine selectively with

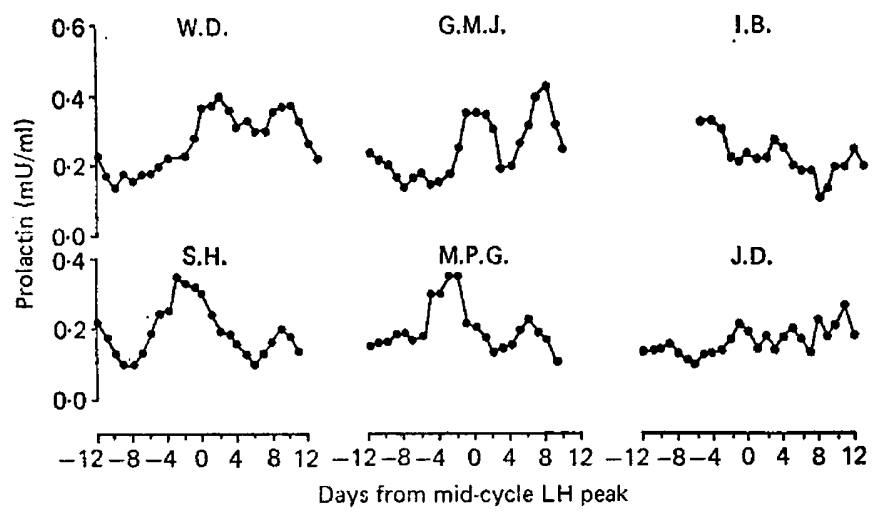

Text-fig. 8. Prolactin levels during the menstrual cycles of 6 normal women. Subjects W.D., G.M.J., S.H. and M.P.G. showed hormone peaks at mid-cycle and mid-luteal phase. Subjects J.D. and I.B. showed only random hormonal fluctuations. 
a particular antigen to the exclusion of other similar molecules. It must be remembered, however, that this can only be tested by comparing the affinity of the antiserum for a labelled preparation of the antigen molecules with its affinity for a variety of non-labelled molecules, including the antigen. Therefore, both the quality of the preparation of the labelled antigen and the purity of the unlabelled materials, including the antigen before labelling, play a major part in assigning specificity to an antiserum. One should, therefore, refer to the specificity of an assay rather than to that of an antiserum in isolation.

Text-figure 9(a) shows the cross-reaction data of an anti-prolactin serum (7110) obtained with a prolactin label provided by Dr U. J. Lewis. This assay is highly specific for human prolactin as there is negligible cross-reactivity with the pituitary glycoproteins or GH.

When the same antiserum (7110) is used with a prolactin label provided by Dr P. Lowry, considerable cross-reactivity with GH is seen (Text-fig. $9 \mathrm{~b}$ ) and the assay would be unsuitable for clinical use.

It became apparent after further experiments that antiserum 7110 contains populations of antibodies to human prolactin and other populations of antibodies to $\mathrm{GH}$. Each antibody population is specific for that hormone. With a pure (i.e. GH-free) prolactin label this antiserum will provide an excellent, specific prolactin assay, while with a pure (i.e. prolactin-free) $\mathrm{GH}$ label will provide a specific GH assay.

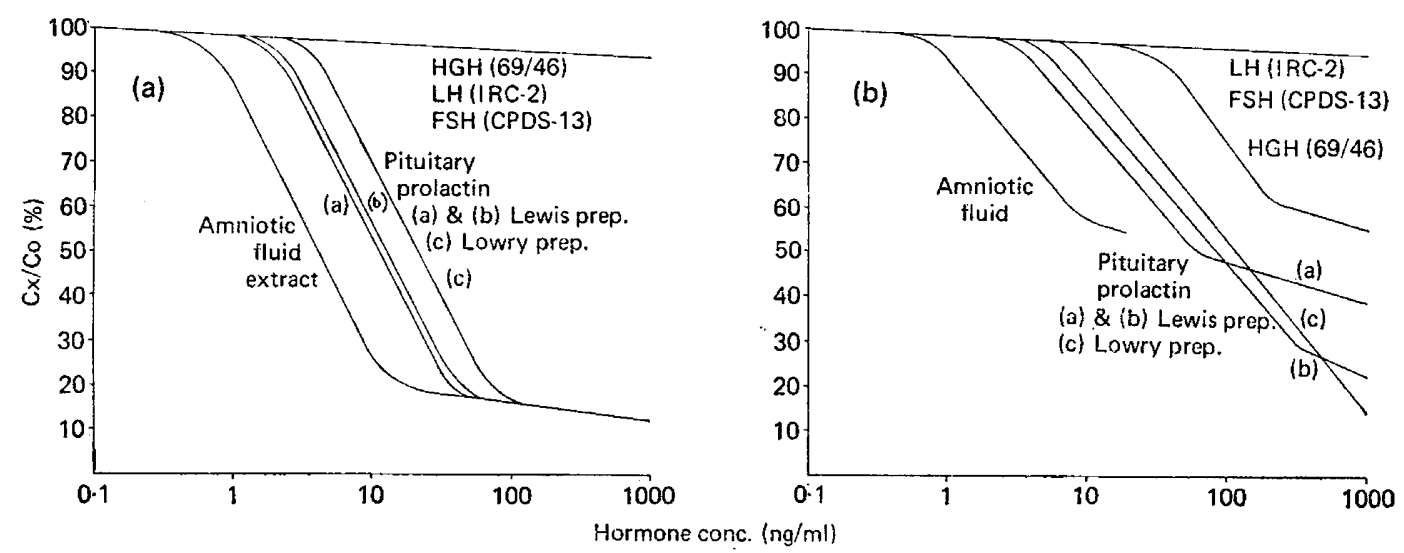

Text-fig. 9. The effect of various pituitary and amniotic fluid hormones on the prolactin assay when antiserum 7110 is used with (a) a 'growth-hormone free' labelled prolactin and (b) a prolactin label containing GH. In (a) parallelism was shown between the prolactin preparations but there was no effect of HGH, LH or FSH on this assay. In (b) a considerable degree of cross-reactivity with GH is evident.

The results of a GH assay performed on these and other purified prolactin preparations are shown in Text-fig. 10. The two Lewis preparations contained approximately $1 \%$ and $10 \% \mathrm{GH}$ contaminants while this batch of Lowry material held some $40 \% \mathrm{GH}$ material. Different batches of purified protein hormone material must be tested individually as the extent of contamination can be expected to differ markedly with each batch. The Lowry prolactin described above could be suitable for use in a prolactin assay which uses an antiserum free of GH antibodies, e.g. R47 raised to an amniotic fluid extract. Antiserum R47, however, contained some antibodies to HCG and a similar problem to that described above arose when an earlier Lewis prolactin preparation, shown to contain some $\mathrm{LH}$, was used as labelled hormone in that prolactin assay. The original prolactin assay with R47 antiserum (Cole \& Boyns, 1973), therefore, utilized HCG to absorb the antibodies to LH/HCG in order to produce a specific prolactin assay, while subsequently with other Lewis prolactin preparations this procedure was found unnecessary (Cole et al., 1976).

Antisera contain heterogeneous mixtures of antibodies to different sites on the antigen. It can be anticipated, therefore, that in considering the RIA of protein hormones different antisera may react with different molecular species of that protein in a plasma sample. This will be affected by the 


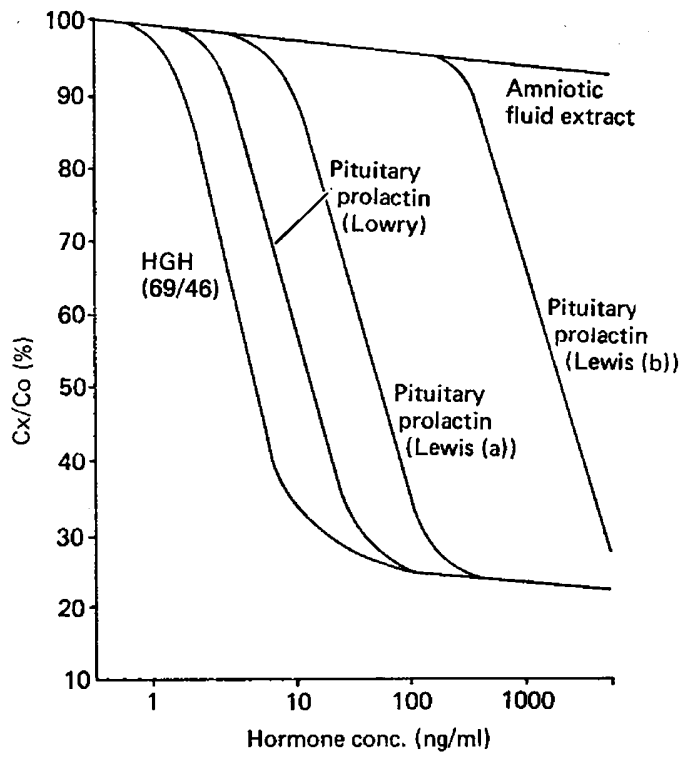

Text-fig. 10. Analysis of the GH content of various prolactin preparations. The graph shows the high level of GH present in the Lowry prolactin in comparison with the two Lewis preparations.

quality of the labelled antigen as already described, but more so by the quality of the antigen initially used for antiserum induction.

Text-figure 11 gives an example of antisera heterogeneity in which a series of plasma samples were assessed in two specific assays for human prolactin, using the same batch of Lewis prolactin for

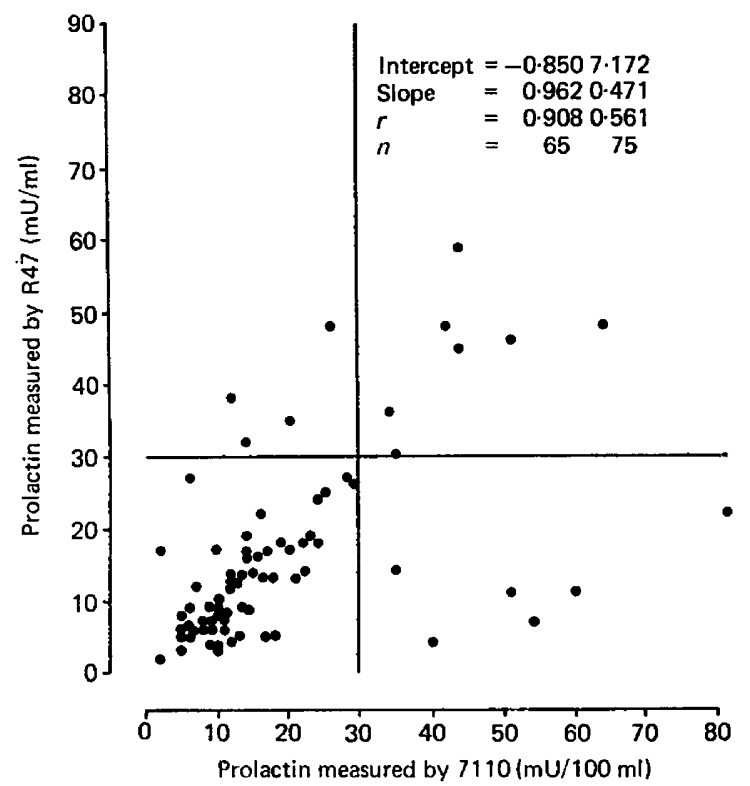

Text-fig. 11. Relationship of human prolactin content of plasma samples assayed with antiserum raised against amniotic fluid extract (R47) or against pituitary extract (7110). While a good correlation existed for the majority of samples, some gave divergent results from the two methods, suggesting that different populations of hormone were being monitored. 
labelling and either antiserum $\mathrm{R} 47$, raised to an amniotic fluid antigen, or antiserum 7110 , raised to a pituitary antigen. For over $86 \%$ of the samples a good correlation existed $(r=0.908)$ between the result obtained from each assay. However, a gross discrepancy is apparent when one considers the remaining samples, such that levels within the normal range by one assay were reported as elevated when the other assay was used. This phenomenon is undoubtedly a result of the different nature of the antigens used to produce the antisera and to the molecular heterogeneity of plasma prolactin (Suh \& Frantz, 1974).

\section{Conclusion}

The measurement of protein hormones by RIA has become so familiar that there is a real danger, with the ever-increasing availability of RIA kits, that serious problems could arise in what has become a relatively routine assay procedure. The aim of this report was to outline some of the diffculties that can be encountered. Far from being commonplace, elementary biochemistry, protein hormone RIA is probably open to more problems and pitfalls than the RIA of steroid hormones and drugs which succeeded it. At least in those cases there is a crystalline material for standard and label and, with suitable chemistry, an equally pure antigen can be produced. As devolution of hormone assays to local chemical pathology departments occurs, it is vital that the laboratories are aware of the limitations of the assays and that the clinicians in their turn realize the problems that can arise in interpreting the data from these assays. The radioimmunoassay has revolutionized clinical endocrinology, but it must be kept in perspective with other assay techniques: each monitors different aspects of hormonal action and the real picture of the significant changes which are taking place in the body will only emerge from a combination of data from each type of assay.

I should like to acknowledge the financial support of the Tenovus Organisation during this work and the excellent assistance of Liz Phillips and Janet Link with some of the assays reported here.

\section{References}

Bahl, O.P., Carlsen, R.B., Bellisario, R. \& Swaminathan, N. (1972) Human chorionic gonadotrophin: amino acid sequence of the alpha and beta subunits. Biochem. Biophys. Res. Commun. 48, 416-422.

Bahl, O.P., Pandian, M.R. \& Ghal, R.D. (1976) Immunological properties of the $\beta$-subunit of human chorionic gonadotrophin. Biochem. Biophys. Res. Commun. 70, 525-532.

Benveniste, R., Frohman, L.A., Bell, J., Spitz, I. \& RABINOWITZ, D. (1975) $\alpha$-Subunit of glycoprotein hormones: presence in peripheral serum after LHRH. Eur. J. clin. Invest. 5, 123-131.

BerLe, P., Apostolakis, M. \& LiNK, A. (1971) Nachweis lakotroper Aktivitat im Plasma wahrend des ovariellen Cyclus der Frau. Arch. Gynak. 210, 124130.

BoYNs, A.R. \& Griffiths, K. (1972) Prolactin and Carcinogenesis. Alpha Omega Alpha, Cardiff.

Braunstein, G.D., Rasor, J. \& Wade, M.E. (1975) Presence in normal human testes of a chorionic gonadotrophin-like substance distinct from human LH. New Engl. J. Med. 293, 1339-1343.

Cole, E.N. \& BoYNs, A.R. (1973) Radioimmunoassay for human pituitary prolactin using an antiserum against an extract of human amniotic fluid. Horm. Res. 4, 261-273.
Cole, E.N. Groom, G.V., Link, J., O'Flanagan, P.M. \& SeldruP, J. (1976) Plasma prolactin concentrations in patients on clomipramine. Postgrad. med. J. 52, (Suppl. 3), 93-100.

Coppedge, R.L. \& Segalofp, A. (1951) Urinary prolactin excretion in man. J. clin. Endocr. Metab. 11, 465-476.

Crowe, S.J., Cushing, H. \& Homans, J. (1910) Experimental hypophysectomy. Bull. Johns Hopkins Hosp. 21, 127-169.

del Pozo, E., Goldstein, M., Friesen, H., Brun del RE, R. \& EPPENBERGer, U. (1975) Lack of action of prolactin suppression on the regulation of the human menstrual cycle. Am. J. Obstet. Gynec. 123, 719-723.

Ehara, Y., Siler, T., Vandenberg, G., Sinha, Y.N. \& YEN, S.S.C. (1973) Circulating prolactin levels during the menstrual cycle: episodic release and diurnal variation. Am. J. Obstet. Gynec. 117, 962970.

Evans, H.M. \& LoNG, J.A. (1921) Characteristic effects upon growth, oestrus and ovulation induced by intraperitoneal administration of fresh anterior hypophyseal substance. Anat. Rec. 21, 62.

Franchimont, P., Gaspard, U., Reuter, A. \& Heynen, G. (1972) Polymorphism of protein and polypeptide hormones. Clin. Endocr. 1, 315-336. 
Greenwood, F.C., Hunter, W.M. \& Glover, J.S. (1963) The preparation of 131-I-labelled human growth hormone of high specific radioactivity. Biochem. J. 89, 114-123.

GreEP, R.O. (1961) Physiology of the anterior hypophysis in relation to reproduction. In Sex and Internal Secretions, Vol. 1, pp. 240-310. Ed. W. C. Young, Williams \& Wilkins, Baltimore.

Griffiths, B.W. \& Godard, A. (1975) Molecular heterogeneity and instability of radioiodinated HCG. Clin. Biochem. 8, 400-408.

Groom, G.V. \& Boyns, A.R. (1973) Gonadotrophin release from human foetal pituitary cultures induced by fragments of the luteinizing hormone-releasing hormone. FEBS Letters 33, 57-60.

Groom, G.V. \& Griffiths, K. (1976) Effect of the anti-oestrogen Tamoxifen on plasma levels of luteinizing hormone, follicle stimulating hormone, prolactin, oestradiol and progesterone in normal premenopausal women. $J$. Endocr. 70, 421-428.

Groom, G.V., Groom, M.A., Cooke, I.D. \& Boyns, A.R. (1971) The secretion of immunoreactive luteinizing hormone and follicle stimulating hormone by the human foetal pituitary in organ culture. $J$. Endocr. 49, 335-344.

HAGEN, C. \& MCNeIlly, A.S. (1975) Gonadotrophic hormones and their subunits in human maternal and fetal circulation at delivery. Am. J. Obstet. Gynec. 121, 926-930.

Hwang, P., Guyda, H. \& Friesen, H. (1971) A radioimmunoassay for human prolactin. Proc. natn. Acad. Sci. U.S.A. 68, 1902-1906.

Kourides, I.A., Weintraub, B.D., Ridgway, E.C. \& MALOOF, F. (1973) Increase in the beta subunit of human TSH in hypothyroid serum after TRH. $J$. clin. Endocr. Metab. 37, 836-840.

LiaO, T.H. \& Pierce, J.G. (1970) The presence of a common type of subunit in bovine TSH and $\mathrm{LH}$. J. biol. Chem. 245, 3275-3281.

Loewenstein, M.S., KuPchick, H.Z. \& ZamCHeCK, N. (1976) Disparity between CEA-Roche "indirect" and "direct" CEA levels: clinical relevance. New Engl. J. Med. 294, 1123.

MCKerNs, K.W. \& RYSChKewITsCh, W. (1974) Interaction of luteinizing hormone and its subunits in corpus luteum supernatant. Endocrinology 95, 847-853.

McNeilly, A.S. \& Chard, T. (1974) Circulating levels of prolactin during the menstrual cycle. Clin. Endocr. 3, 105-112.

NAKANE, P.K. (1970) Classification of anterior pituitary cell types with immunoenzyme histochemistry. $J$. Histochem. Cytochem. 18, 9-20.

PAPKOFF, H. \& SAMY, T.S.A. (1967). Isolation and partial characterisation of the polypeptide chains of ovine ICSH. Biochim. biophys. Acta 147, 175-177.

Phifer, R.F., Midgley, A.R. \& SPICER, S.S. (1973) Immunohistologic and histologic evidence that FSH and $\mathbf{L H}$ are present in the same cell type in the human pars distalis. J. clin. Endocr. Metab. 36, 125141.

REEs, L.H. (1975) The biosynthesis of hormones by non-endocrine tumours-a review. $J$. Endocr. 67, 143-175.
Reichert, L.E. \& Midgley, A.R. (1968) Preliminary studies of the effect of urea and chymotrypsin on the molecular, biological and immunological properties of human FSH and LH. In Gonadotropins, pp. 25-33. Ed. E. Rosemberg. Geron-X California.

ReicherT, L.E., Midgley, A.R., Niswender, G.D. \& WARD, D.N. (1970) Formation of hybrid molecule from subunits of human and bovine luteinizing hormone. Endocrinology 87, 534-541.

Robyn, C., Delvoye, P., Nokin, J., Vekemans, M., Badawi, M., Perez-lopez, F.P. \& L'Hermite, M. (1973) Prolactin and human reproduction. In Int. Symp. Human Prolactin, p. 98-112. Eds J. L. Pasteels \& C. Robyn. Excerpta Medica, Amsterdam.

Rouslaht, E. \& TERRY, W.D. (1976) $\alpha$-Foetoprotein and serum albumin show sequence homology. Nature, Lond. 260, 804-805.

Ryan, R.J., JiAng, N.S. \& HANLON, S. (1971) Physical properties of human FSH. Biochemistry, N.Y. 10, 1321-1329.

Schally, A.V., Arimura, A., Debeljuk, L., Redding, T.W. \& ReEVES, J.J. (1973) Hypothalamic hormones regulating pituitary function; their physiology and biochemistry. In Hypothalamic Hypophysiotropic Hormones: Physiological and Clinical Studies, p. 8. Eds C. Gual \& E. Rosemberg. Excerpta Medica, Amsterdam.

Schally, A.V., Arimura, A., Kastin, A.J., Matsuo, H., BabA, Y., Redding, T.W., NaIr, R.M.G., DeBeluUK, L. \& WhITE, W.F. (1971) Gonadotrophinreleasing hormone-one polypeptide regulates the secretion of LH and FSH. Science, N.Y. 173, 1036-1038.

Schwartz, N.B. \& McCormaCK, C.E. (1972) Reproduction: gonadal function and its regulation. $A$. Rev. Physiol. 34, 425-472.

Shahmanesh, M., Boyns, A.R., Ellwood, M., Groom, G.V., Nelson, E. \& Hartog, M. (1975) The response to luteinizing hormone-releasing hormone in normal men. Postgrad. med. J. 51, 59-64.

Shahmanesh, M. \& Jeffcoate, S.L. (1976) Absence of of an immunologically distinct follicle stimulating hormone releasing factor in rat stalk median eminence extracts. J. Endocr. 68, 89-94.

Shome, B. \& Parlow, A.F. (1973) The primary structure of the hormone-specific beta subunit of human pituitary LH. J. clin. Endocr. Metab. 36, 618-621.

SteVens, V.C. \& VorYs, N.E. (1967) Regulation of pituitary function by sex steroids. Obstet. Gynec. Survey 22, 781-811.

SUH, H.K. \& FRANTZ, A.G. (1974) Size heterogeneity of human prolactin in plasma and pituitary extracts. J. clin. Endocr. Metab. 39, 928-935.

Thorner, M.O., McNeilly, A.S., Hagen, C. \& Besser, G.M. (1974) Long-term treatment of galactorrhoea and hypogonadism with bromocryptine. $B r$. med. J. ii, 419-422.

VAITUKaITIS, J.L. (1975a) Chorionic gonadotrophin and its subunits. In Placental Proteins and their Subunits as Tumor Markers. NIH Conference. Ann. Int. Med. 82, 71-83.

VAITUKAITIS, J.L. (1975b) When is a tumor marker not a tumor marker? New Engl. J. Med. 293, 1370-1371. 
Vaitukattis, J.L., Braunstein, G.D. \& Ross, G.T. (1972) A radioimmunoassay which specifically measures human chorionic gonadotrophin in the presence of human luteinizing hormone. $A m$. J. Obstet. Gynec. 113, 751-758.

Ward, D.N., ReicherT, L.E., Fitax, B.A., NahM, H.S., SWEENEY, C.M. \& NEILL, J.D. (1971) Isolation and properties of subunits of rat pituitary LH. Biochemistry, N.Y. 10, 1796-1802.

Young, J.L., Harsoulis, P., KukU, S.F. \& Fraser, T.R. (1975) Gel filtration of human urinary immunoreactive luteinizing hormone. J. Endocr. 64, 429-441

Young, J.L., REID, R.G. \& CraWford, J.W. (1976) Purification and radioimmunoassay of human a-1-foetoprotein: the effects of aggregates on the radioimmunoassay. Clin. chim. Acta 69, 11-20.

ZoNDEK, B. (1930) Uber die Hormon des Hypophysenvordenlappen. I. Wachstumhormon, Follikelreifungshormon (Prolan A). Luteinisierungshormon (Prolan B). Stoffweicksenhormon. Klin. Wschr. 9, 245-258. 